\title{
Cardioprotective Benefits and Nutritional Criteria of Omega -3 Fatty Acids
}

\author{
Anugya Bharti* and Archana Kushwaha \\ Department of Foods and Nutrition, GB Pant University of Agriculture and Technology, \\ Pantnagar, Uttarakhand - 263145, India \\ *Corresponding author
}

\section{A B S T R A C T}

Keywords

Pro-atherogenic,

Left ventricle

hypertrophy,

Eicosanoid, Fibrous

cap, Arrhythmia

Article Info

Accepted:

15 December 2019

Available Online:

20 January 2020
CVD is a major public health problem. High blood pressure and circulating LDL levels are major risk factors for promoting atherosclerosis, ischemic heart disease or stroke. PUFA act as substrates for eicosanoid formation. Eicosanoids formed from omega 3 are anti- inflammatory in nature and possess cardioprotective effects through various mechanisms with DHA being most potent followed by EPA and ALA in preventing cardiovascular disease. But conversion of ALA to EPA and DHA is less efficient. So, walnuts and flaxseed being very good source of ALA should be included in the diet with dose depending on the severity of disease. Along with this, consumption of fatty fish at least 2 servings per week or fish oil supplementation is necessary for reducing the risk of cardiovascular disease.

\section{Introduction}

Cardiovascular disease (CVD) is a class of diseases that involve the heart or blood vessel. Cardiovascular diseases involving heart are cardiomyopathy, hypertensive heart disease, heart failure, pulmonary heart disease, cardiac dysrhythmias (abnormalities of heart rhythm) and inflammatory heart disease. Diseases of blood vessels involves coronary artery disease $(\mathrm{CAD}) /$ coronary heart disease (CHD)/ ischemic heart disease (IHD) that includes angina and myocardial infarction (commonly known as a heart attack), peripheral arterial disease, cerebrovascular disease/ stroke and renal artery stenosis (Cardiovascular disease).

CVD is a major public health problem in India. Cardiovascular disease has become the leading cause of mortality in India (Reddy et al., 2005) and throughout the world. The epidemiological transition from infectious diseases to non-communicable diseases (NCDs) is seen in India in last two decades (Institute of Health Metrics and Evaluation. GBD Profile: India). Annual Indian stroke 
incidence rate is 154 per 100000 (standardized to the world standard population) (Das and Banerjee, 2008) with higher among women Hypertensive heart disease is most common problem while rheumatic heart disease and atrial fibrillation are less common and attributes to other type of CVD such as aortic aneurysms, peripheral vascular disease, and endocarditis and ultimately increases the burden of mortality and morbidity among Indians.

\section{Major risk factors for cardiovascular disease}

\section{Atherosclerosis}

Atherosclerosis is a disease of the arterial wall (Insull 2009). Atherosclerosis is the usual cause of heart attacks, stroke and peripheral vascular disease. The normal arterial vessel consists of three layers namely intima (innermost layer), media and outer layer adventitia. Intima is composed of a single layer of endothelial cells (endothelium), connective tissue, and several smooth muscle cells. Endothelial cells of the intima layer perform two major functions. Firstly, it produces antithrombotic molecules such as heparin sulfate, thrombomodulin, and plasminogen, prostacyclin and nitric oxide (NO), thus, prevents blood clotting. Secondly, vasodilators such as nitric oxide, prostacyclin and vasoconstrictors such as endothelin are produced by endothelial cells that help in contraction of smooth muscle cells in the media. This endothelial-dependent response is called flow-mediated vasodilation (FMD). Impairment of FMD can be used for clinical diagnosis of endothelial function and for early detection of atherosclerosis (Delewi et al.,).

Various risk factors for atherosclerosis such as diabetes, hypertension, cigarette smoking and abnormally high circulating LDL levels leads to pro-atherogenic conditions (Krouwer et al.,
2012) and endothelial dysfunction that disrupts the integrity of barrier provided by the endothelial cells. This allows circulating high level of LDL to enter the intima. LDL particles bind to proteoglycans, start to accumulate and get oxidised thus causing tissue damage. Damage to intima induces monocyte recruitment, gets differentiated into phagocytic macrophages that plays crucial role in formation of foam cells (Chistiakov et al., 2017). In addition, vascular smooth muscle cells migrate from the media to the intima, proliferate and get differentiated into macrophages (Lao et al., 2015) and ultimately transformed into foam cells (Yu et al., 2013) by absorbing lipoproteins.

Foam cell increases in size and intensify plaque formation. In the media, smooth muscle cell is responsible for the production of vascular extracellular matrix consisting of elastin, proteoglycans and fibrillar collagen (Munro and Cotran 1988). Migration of smooth muscle cells from media to intima and the secretion of large amounts of collagen firstly give rise to fibrous lesions consisting of lipid-loaded macrophages and smooth muscle cells covered by a fibrous cap (Tabas 2002) and secondly, shifts the balance towards extracellular matrix metabolism. This activates apoptosis pathway resulting in death of smooth muscle and foam cells.

Diminished collagen synthesis weaken the fibrous cap strength ultimately results into rapture of atherosclerotic plaque (Cullen et al., 2003; Arroyo and Lee 1999). Atheroma may go through episodes of haemorrhage with or without calcification. Rapture of plaque initiate both platelet adhesion and aggregation on the exposed vascular surface and the activation of the coagulation cascade, leading to thrombosis, progressive vessel narrowing and may may result in myocardial infarction or sudden death (Legein et al., 2013). 


\section{Hypertension}

Left ventricle hypertrophy (LVH) becomes an independent risk factor for congestive heart failure, ischemic heart disease, arrhythmia, sudden death (Katholi and Couri 2011) and stroke. An increase in left ventricular wall stress caused by high blood pressure stimulates collagen formation and hypertrophy of the myocardium with a disproportionate increase in fibrous tissue that impairs left ventricular diastolic function (Kahan and Bergfeldt 2005). These changes lead to a progressive decline in contractility of heart (Vasan et al., 1999) and ultimately cardiac ischemia, myocardial infarction or heart failure (Torpy et al., 2004).

\section{PUFA (Polyunsaturated Fatty acid)}

PUFAs act as substrates for eicosanoid formation. Some are proinflammatory in nature whereas some are beneficial. PUFAs also serve as substrates for lipid oxidation and the production of reactive oxygen species. The more common PUFAs in our diet are the omega (n)-6 and n-3 fatty acids. PUFA should provide $6-10 \%$ of total energy. Sources of Linoleic acid (LA) or omega 6 polyunsaturated fatty acid are vegetable oils such as safflower and corn oils whereas major source of alpha linolenic acid are plant sources that includes flaxseed and walnuts and long chain omega-3 polyunsaturated fatty acids ( $\mathrm{n}-$ 3 LC PUFAs) that includes Eicosapentanoic acid (EPA) and Docosahexaenoic Acid (DHA) are abundantly found in fish and fish oil.

\section{PUFA metabolism}

Linoleic acid and ALA on consumption undergoes a series of desaturation and elongation steps to produce highly unsaturated longer-chain arachidonic acid (AA) in $n-6$ pathway and eicosapentaenoic acid (EPA) and docosahexaenoic acid (DHA) in $n-3$ pathway
(Engler and Engler 2006). AA and EPA compete with each other for release by phospholipases and for conversion into potent regulatory eicosanoids in the tissue membrane (Harris 2006). Free AA serves as a substrate for the enzymes cyclooxygenases (COX - 2) to produce two-series prostaglandins (PGE2) (vasodilator), prostacyclins (PGI2) (platelet aggregator) and thromboxanes (TXA2) (vasoconstrictor) (Lagarde et al., 2018) eicosanoids that are pro - inflammatory in nature. n-3 PUFA plays beneficial role in shifting the production of AA-derived pro inflammatory eicosanoids to anti inflammatory eicosanoids by competing with AA for incorporation into cell membrane or by inhibiting the enzymes COX-2 (Chitranjali et al., 2015) thereby decreasing two- and fourseries PG and TX production and increasing the three- and five-series PG, PGI and TX production (Adkins and Kelley 2010).

\section{Mechanism of action of Omega - 3 fatty acid}

The cardioprotective effect of Omega - 3 fatty acid is well established and in this section, we will briefly review to extend our knowledge.

\section{Lipid lowering effect}

Hypertriglyceridemia can promote atherogenesis and is an important independent risk factor for coronary heart disease. Omega3 fatty acids are best known for their triglyceride-lowering effect (Benes et al., 2018) by reducing hepatic VLDL synthesis and by clearance of triglyceride from serum. $\mathrm{n}$ - 3 PUFA reduces VLDL triglyceride synthesis by three mechanisms. Firstly $n-3$ PUFA reduces the substrate i.e. fatty acid needed for triglyceride synthesis either by increase in $\beta$-oxidation (Rombaldova et al., 2017) or by decreasing hepatic delivery of non- esterified free fatty acids or by reducing lipogenesis. Another way for reducing 
triglyceride synthesis is by shift of lipid synthesis toward phospholipids rather than triglycerides or by reducing the activity of hepatic enzyme such as diacylgylcerol acyltranferase (DGAT) or phosphatidic acid phosphohydrolase (PAP) (Harris and Bulchandani 2006; Scorletti and Byrne 2018). Omega-3 fatty acid also increases lipoprotein lipase activity, thus increase serum clearance of triglyceride (Harris et al., 2008). However, this may cause an increase in low-density lipoprotein cholesterol that can be considered part of the normal physiologic process in correcting high triglyceride (Samuel et al., 2011) but may not be harmful in present context. Change in triglyceride level is inversely correlated with the LDL particle size. Lowering triglyceride level causes an increase in LDL particles of larger size (Mori et al., 2000) that may be anti- atherogenic in nature rather than atherogenic effect (Jacotot 1996). Supplementation with docosahexanoic acid is possibly being more effective than eicosapentanoic acid and ALA (Kelley et al., 2007; Maki et al., 2005; Scorletti and Byrne 2018) in treating hypertriglyceridemia and secondary prevention of $\mathrm{CV}$ disease such as myocardial infarction and cardiac death (Arca et al., 2017).

The key enzyme of cholesterol biosynthesis is 3-hydroxy-3-methyl-glutaryl CoA (HMGCoA) reductase. $n-3$ PUFA suppresses the expression of $\mathrm{HMG}-\mathrm{CoA}$ reductase enzyme thus, prevent cholesterol synthesis and convert excess cholesterol into bile (Balogun and Cheema, 2015). Supplementation with n-3 PUFA also exerts its cardioprotective effect by increasing the concentration of HDL cholesterol in the blood (Dunstan et al., 1997).

\section{Anti-arrhythmic effects}

Anti - arrhythmic effect of n- 3 fatty acid is mediated through electrical stabilization of myocytes (Harrison and Abhyankar 2005).
$\mathrm{Ca} 2+, \mathrm{Na}+$, and $\mathrm{K}+$ are important regulators of membrane excitability and contractility and decrease in uniformity in this has shown to result in decreased cardiac contractility and increased incidence of arrhythmias (Doshi and Marx 2009). EPA and DHA modulate the activity of calcium channels (Endo and Arita 2016) whereas EPA blocks the sodiumcalcium channel thus helps to prevent fatal arrhythmia (Xiao et al., 2001). DHA being the most potent $n-3$ PUFA followed by EPA and ALA (Moreno et al., 2012).

\section{Anti - thrombotic effect}

Supplementation with long-chain omega-3 polyunsaturated fatty acid (LCn-3 PUFA) plays a significant role in reducing the risk of cardiovascular disease due to its antiinflammatory and anti-thrombotic effects (Adili et al., 2017). Platelet aggregation plays a pivotal role in the development of CVD by initiation of process of thrombosis (Jackson 2007). Consumption of n-3 PUFAs reduces formation of the platelet activator Thromboxane A2 (TXA2) by increasing the concentration of Prostacyclin or PGI2 that act as vasodilator and platelet inhibitor (Lagarde et al., 2018). Thus, production of plateletactivating factor (PAF) is suppressed resulting in inhibition of platelet aggregation (DeCaterina et al., 1990; Dyerberg et al., 1978). Thus, n-3 PUFA-supplementation reduces ADA (adenosine diphosphate), collagen and arachidonic acid induced platelet aggregation (Gao et al., 2013) and consequently increases bleeding time but within safe limit with no adverse effects on human health (Jeansen et al., 2017). Among n - 3 LC PUFA, EPA was more effective than DHA in males (Phang et al., 2009) whereas in females, DHA was more effective in reducing platelet aggregation. This may be due to inverse relationship between testosterone levels and EPA supplemented platelet aggregation (Phang et al., 2012). 
Table.1 Summary of beneficial effects of flaxseed supplementation on various cardiovascular outcomes

\begin{tabular}{|c|c|c|c|c|}
\hline Reference & Subjects & $\begin{array}{l}\text { Dose and } \\
\text { Duration/ } \\
\text { Treatment }\end{array}$ & Placebo & Outcome \\
\hline $\begin{array}{l}\text { (Akrami et al., } \\
\text { 2018) }\end{array}$ & $\begin{array}{l}30 \text { to } 60 \text { years old } \\
\text { diagnosed } \text { with } \\
\text { Metabolic Syndrome }\end{array}$ & $\begin{array}{l}25 \quad \mathrm{~mL} / \mathrm{d} \\
\text { Flaxseed oil } \\
\text { for } 7 \text { weeks }\end{array}$ & $\begin{array}{l}\text { Sunflower } \\
\text { oil }\end{array}$ & $\begin{array}{l}\text { Reduction in SBP, } \\
\text { DBP, LDL and TG }\end{array}$ \\
\hline $\begin{array}{l}\text { (Bloedon et al., } \\
\text { 2008) }\end{array}$ & $\begin{array}{l}\text { Men and Post- } \\
\text { menopausal women } \\
\text { between the ages of } \\
44 \text { and } 75 \text { with } \\
\text { hypercholesterolemia }\end{array}$ & $\begin{array}{l}40 \quad \mathrm{~g} / \mathrm{day} \\
\text { flaxseed for } 10 \\
\text { weeks }\end{array}$ & $\begin{array}{l}\text { Wheat } \\
\text { bran }\end{array}$ & $\begin{array}{l}\text { Increased serum } \\
\text { levels of ALA } \\
\text { Significant } \\
\text { reduction in total } \\
\text { cholesterol, LDL-C, } \\
\text { Apo- B and } \\
\text { HOMA-IR index }\end{array}$ \\
\hline $\begin{array}{l}\text { (Dodin et al., } \\
\text { 2008) }\end{array}$ & Menopausal women & $\begin{array}{l}40 \mathrm{~g} / \mathrm{d} \text { of } \\
\text { flaxseed for } 12 \\
\text { months }\end{array}$ & $\begin{array}{l}\text { Wheat } \\
\text { germ }\end{array}$ & $\begin{array}{l}\text { Significant increase } \\
\text { in apo A-1, EPA, } \\
\text { ALA, HDL } \\
\text { Significant decrease } \\
\text { in LDL and total } \\
\text { plasma cholesterol }\end{array}$ \\
\hline $\begin{array}{l}\text { (Machado et } \\
\text { al., 2015) }\end{array}$ & $\begin{array}{l}\text { Overweight } \\
\text { adolescents }\end{array}$ & $\begin{array}{l}28 \mathrm{~g} / \mathrm{d} \text { of } \\
\text { flaxseed for } 11 \\
\text { weeks }\end{array}$ & $\begin{array}{l}\text { Wheat } \\
\text { bran }\end{array}$ & $\begin{array}{l}\text { Significant } \\
\text { reduction in the } \\
\text { DBP, TG } \\
\text { Increase in HDL } \\
\text { level }\end{array}$ \\
\hline $\begin{array}{l}\text { (Paschos et al., } \\
\text { 2007) }\end{array}$ & $\begin{array}{l}\text { Male aged } 35 \text { to } 70 \\
\text { years, first diagnosed } \\
\text { for dyslipidaemia, } \\
\text { without evidence of } \\
\text { CHD }\end{array}$ & $\begin{array}{l}15 \mathrm{ml} \text { of } \\
\text { flaxseed oil per } \\
\text { day for 12- } \\
\text { week }\end{array}$ & $\begin{array}{l}\text { Safflower } \\
\text { oil }\end{array}$ & $\begin{array}{l}\text { Significant decrease } \\
\text { in SBP and DBP by } \\
\text { approx. } 5 \mathrm{~mm} \mathrm{Hg} \text { or } \\
3-6 \% \text {. }\end{array}$ \\
\hline $\begin{array}{l}\text { (Pilar et al., } \\
\text { 2014) }\end{array}$ & $\begin{array}{l}\text { Metabolic syndrome } \\
\text { persons of } 45 \text { and } \\
55 \text { years of age }\end{array}$ & $\begin{array}{l}40 \mathrm{~g} / \text { day } \text { of } \\
\text { golden } \\
\text { flaxseed for } 28 \\
\text { days }\end{array}$ & --- & $\begin{array}{l}\begin{array}{l}\text { Reduction in } \\
\text { LDL, } \\
\text { cholesterol } \\
\text { Significant } \\
\text { reduction }\end{array} \\
\text { TBARS level } \\
\text { Increase in plasma } \\
\text { HDL level }\end{array}$ \\
\hline $\begin{array}{l}\text { (Ricklefs- } \\
\text { Johnson et al., } \\
\text { 2017) }\end{array}$ & $\begin{array}{l}\text { Adults between 18- } \\
75 \text { years of age } \\
\text { diagnosed with T2D } \\
\text { at least } 6 \text { months } \\
\text { prior to enrollment }\end{array}$ & $\begin{array}{l}28 \mathrm{~g} / \mathrm{d} \text { of } \\
\text { ground } \\
\text { flaxseed for } 8 \\
\text { weeks }\end{array}$ & $\begin{array}{l}\text { Ground } \\
\text { psyllium }\end{array}$ & $\begin{array}{l}\text { Reduction in } \\
\text { Cholesterol, LDL- } \\
\text { C, TBARS and } \\
\text { increase in Nitric } \\
\text { Oxide }\end{array}$ \\
\hline
\end{tabular}


Table.2 Summary of beneficial effects of fish oil supplementation on various cardiovascular outcomes

\begin{tabular}{|c|c|c|c|c|}
\hline Reference & Subjects & $\begin{array}{l}\text { Dose / } \\
\text { Treatment }\end{array}$ & Duration & Outcome \\
\hline $\begin{array}{l}\text { (Alfaddagh } \\
\text { et al., 2017) }\end{array}$ & $\begin{array}{lr}\text { Patients } & \text { mean } \\
\text { age } 63.0 & \text { years } \\
\text { with } & \text { stable } \\
\text { coronary } & \text { artery } \\
\text { disease } & \end{array}$ & $\begin{array}{l}1.86 \mathrm{~g} \text { of } \mathrm{EPA} \\
\text { and } 1.5 \mathrm{~g} \text { of } \\
\text { DHA/ day }\end{array}$ & 30 months & $\begin{array}{l}\text { Subjects aged }<64.2 \text { years had } \\
\text { significantly less progression } \\
\text { of non calcified plaque } \\
((\mathrm{P}=0.013) \text { (primary endpoint) } \\
\text { and fibrous, calcified, and total } \\
\text { plaque volume compared with } \\
\text { older subjects. }\end{array}$ \\
\hline (Bays 2006) & $\begin{array}{l}\text { patients with } \\
\text { myocardial } \\
\text { infarction (MI) }\end{array}$ & $\begin{array}{l}4 \quad \text { capsules/day } \\
(2 \quad \text { capsules } \\
\text { given twice } \\
\text { daily) alone or } \\
\text { in combination } \\
\text { with (HMG- } \\
\text { CoA) reductase } \\
\text { inhibitors } \\
\text { capsule } \\
\text { containing } 465 \\
\text { mg of EPA and } \\
375 \text { mg of DHA } \\
\text { along with } 4 \text { mg } \\
\text { (6 IU) of } \\
\text { vitamin E }\end{array}$ & 6 months & $\begin{array}{l}\text { Increases high-density } \\
\text { lipoprotein cholesterol levels } \\
\text { Helps in controlling } \\
\text { hypertriglyceridemia } \\
\text { Mildly increases plasma levels } \\
\text { of low-density lipoprotein } \\
\text { cholesterol }\end{array}$ \\
\hline $\begin{array}{l}\text { (Casanova } \\
\text { et al., 2017) }\end{array}$ & $\begin{array}{l}\text { Adults with } \\
\text { triglycerides } \\
150-499 \mathrm{mg} / \mathrm{dL}\end{array}$ & $\begin{array}{l}1800 \quad \mathrm{mg} / \text { day } \\
(60 \% \mathrm{EPA} \text { and } \\
40 \% \mathrm{DHA})\end{array}$ & 12 weeks & $\begin{array}{l}\text { Significant reduction in } \\
\text { peripheral and aortic systolic } \\
\text { blood pressure, pulse wave } \\
\text { velocity and improvement in } \\
\text { flow-mediated dilation }\end{array}$ \\
\hline $\begin{array}{l}\text { (Caniato et } \\
\text { al., 2006) }\end{array}$ & $\begin{array}{l}\text { Subjects } \\
\text { suffering from } \\
\text { schizophrenia } \\
\text { or } \\
\text { schizoaffective } \\
\text { disorder }\end{array}$ & $\begin{array}{l}10 \mathrm{~g} \text { of fish oil } \\
\text { capsule (Each } 1 \\
\mathrm{gm} \mathrm{capsule} \\
\text { contained } \\
\text { approximately } \\
180 \mathrm{mg} \text { of EPA } \\
\text { and } 120 \mathrm{mg} \text { of } \\
\text { DHA) }\end{array}$ & $\begin{array}{l}28 \text { days (4 } \\
\text { weeks) }\end{array}$ & $\begin{array}{l}\text { Statistically } \\
\text { reduction in mean serum } \\
\text { triglyceride levels of } 22 \% \text {. } \\
\text { Increase in total cholesterol } \\
\text { and low-density lipoprotein } \\
\text { cholesterol by } 6.6 \% \text { and } 22 \% \text {. }\end{array}$ \\
\hline $\begin{array}{l}\text { (Dokholyan } \\
\text { et al., 2004) }\end{array}$ & $\begin{array}{l}\text { Adults } 30 \text { to } 54 \\
\text { years of age }\end{array}$ & $\begin{array}{l}8 \text { capsules/day } \\
(60 \mathrm{mg} \text { of EPA }\end{array}$ & 12 weeks & $\begin{array}{l}\text { Reductions in DBP and SBP } \\
\text { but not statistically significant }\end{array}$ \\
\hline
\end{tabular}




\begin{tabular}{|c|c|c|c|c|}
\hline & 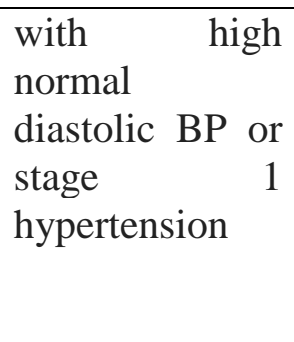 & $\begin{array}{l}\text { plus } 15 \mathrm{mg} \text { of } \\
\text { GLA (4:1 ratio) } \\
\text { and } 10 \text { IU of } \\
\text { vitamin } \mathrm{E} \text { per } \\
\text { capsule) } \\
\text { Placebo - Olive } \\
\text { oil }\end{array}$ & & \\
\hline $\begin{array}{ll}\text { (Elajami } & \text { et } \\
\text { al., 2017) } & \end{array}$ & 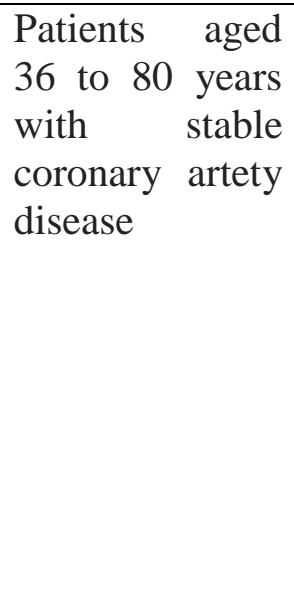 & $\begin{array}{l}4 \text { capsules daily } \\
\text { (Each 1000-mg } \\
\text { capsule } \\
\text { containing } \\
\text { predominantly } \\
\text { EPA (465 } \mathrm{mg} \text { ) } \\
\text { and DHA (375 } \\
\text { mg)) }\end{array}$ & 12 months & $\begin{array}{l}\text { A significant reduction in } \\
\text { triglyceride level } \\
(P<0.001) \text { with increase in } \\
\text { high-density lipoprotein } \\
\text { cholesterol level }(P=0.01) \text { in } \\
\text { non- diabetic subjects } \\
\text { Significant reduction in } \\
\text { triglyceride level }(P=0.005) \\
\text { without a change in } \\
\text { high-density lipoprotein } \\
\text { cholesterol in diabetic subjects }\end{array}$ \\
\hline $\begin{array}{ll}\text { (Grenon } & \text { et } \\
\text { al., 2015) } & \end{array}$ & $\begin{array}{l}\text { Patients aged } \\
50 \text { and older } \\
\text { with } \\
\text { lower-extremity } \\
\text { PAD } \\
\text { (peripheral } \\
\text { artery disease) }\end{array}$ & $\begin{array}{l}8 \text { capsules/day } \\
\text { providing } \\
4.4 \mathrm{~g} / \text { day } \\
\mathrm{n} 3 \text {-PUFA }(325 \\
\mathrm{mg} \text { of EPA and } \\
225 \mathrm{mg} \text { of DHA } \\
\text { per capsule) }\end{array}$ & 1 month & $\begin{array}{l}\text { Improved serum triglyceride } \\
\text { level } \\
\text { Increased the production of } \\
n-3 \text { PUFA-derived products in } \\
\text { patients }\end{array}$ \\
\hline $\begin{array}{ll}(\text { Kenny } & \text { et } \\
\text { al., 1992) } & \end{array}$ & \begin{tabular}{lr}
\multicolumn{2}{l}{ Normotensive } \\
men having \\
blood pressure \\
less than \\
$140 / 90 \mathrm{~mm} \mathrm{Hg}$
\end{tabular} & 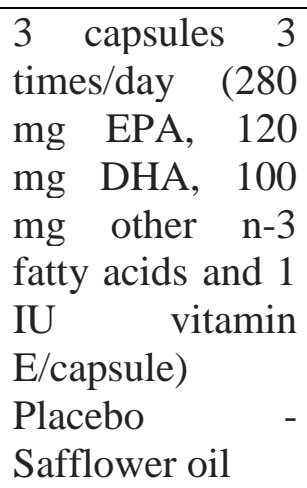 & 7 days & $\begin{array}{l}\text { Significantly reduced vascular } \\
\text { resistance, } \\
\text { triglycerides } \\
\text { Increase in plasma EPA levels }\end{array}$ \\
\hline $\begin{array}{l}\text { (Kumar et } \\
\text { al., 2011) }\end{array}$ & $\begin{array}{l}\text { Patients } 18 \text { to } \\
75 \text { years old } \\
\text { with } \\
\text { paroxysmal } \\
\text { atrial } \\
\text { fibrillation }\end{array}$ & $\begin{array}{l}6 \quad \text { g/day } \\
\text { containing a } \\
\text { total dose of } 1.5 \\
\text { g DHA and } 0.3 \\
\text { g EPA }\end{array}$ & 30 days & $\begin{array}{l}\text { Decreases susceptibility to } \\
\text { initiation atrial fibrillation } \\
\text { within pulmonary vein and } \\
\text { thus has antifibrillatory effect }\end{array}$ \\
\hline
\end{tabular}




\begin{tabular}{|c|c|c|c|c|}
\hline & (PAF) & & & \\
\hline $\begin{array}{l}\text { (Metcalf } \\
\text { al., 2008) }\end{array}$ & $\begin{array}{l}\text { Patients with } \\
\text { ischemic heart } \\
\text { disease }\end{array}$ & $\begin{array}{l}3 \quad \mathrm{~g} / \text { day } \\
\text { encapsulated } \\
\text { fish oil } \\
\text { providing } \quad 540 \\
\text { mg/day EPA and } \\
360 \quad \mathrm{mg} / \text { day } \\
\text { DHA }\end{array}$ & 6 weeks & $\begin{array}{l}\text { Antiarrhythmic effect } \\
\text { Decreases the inducibility of } \\
\text { ventricular tachycardia in } \\
\text { patients at risk of sudden } \\
\text { cardiac death (SCD) }\end{array}$ \\
\hline $\begin{array}{l}\text { (Oikonomou } \\
\text { et al., 2018) }\end{array}$ & $\begin{array}{l}\text { Patients aged } \\
18 \text { to } 80 \text { years } \\
\text { old, } \\
\text { chronic } \\
\text { ischemic heart } \\
\text { Failure, Left } \\
\text { Ventricle } \\
\text { systolic } \\
\text { dysfunction } \\
\text { (Left ventricle } \\
\text { ejection } \\
\text { fraction }<40 \% \text { ) }\end{array}$ & $\begin{array}{l}2 \mathrm{~g} / \text { day }(46 \% \\
\text { eicosapentaenoic } \\
\text { acid and } 38 \% \\
\text { docosahexaenoic } \\
\text { acid) } \\
\text { Placebo - Olive } \\
\text { oil }\end{array}$ & 8 weeks & $\begin{array}{l}\text { Improvement in inflammatory } \\
\text { and fibrotic status, endothelial } \\
\text { function, systolic and diastolic } \\
\text { performance of left ventricle, } \\
\text { left ventricle performance } \\
\text { indices, systemic inflammation } \\
\text { and fibrosis biomarkers }\end{array}$ \\
\hline $\begin{array}{l}\text { (O'Keefe et } \\
\text { al., 2006) }\end{array}$ & $\begin{array}{l}\text { Patient with } \\
\text { myocardial } \\
\text { infarction }\end{array}$ & $\begin{array}{l}3 \text { capsule/day } \\
\text { ( } 75 \mathrm{mg} \text { of EPA } \\
\text { and } 195 \mathrm{mg} \text { of } \\
\text { DHA per 500- } \\
\text { mg capsule) } \\
\text { Placebo - 50:50 } \\
\text { mix of corn and } \\
\text { olive oils }\end{array}$ & $\begin{array}{l}2 \\
\text { sequential } \\
\text { 4-month } \\
\text { periods } \\
\text { (total } 8 \\
\text { months) }\end{array}$ & $\begin{array}{l}\text { Decreases HR at rest from } 73 \\
\pm 13 \text { to } 68 \pm 13 \text { beats/min }(p \\
<0.0001) \\
\text { Improved } 1 \text {-minute } \\
\text { recovery after exercise }(-27 \pm \\
10 \text { to }-32 \pm 12 \text { beats/min, } p \\
<0.01) \\
\text { Increases HR variability (p } \\
<0.02) \\
\text { Decrease the risk for sudden } \\
\text { cardiac death }\end{array}$ \\
\hline $\begin{array}{ll}\text { (Samuel } & \text { et } \\
\text { al., 2011) } & \end{array}$ & $\begin{array}{l}\text { Patients of age } \\
45 \text { to } 75 \text { years } \\
\text { having } \\
\text { triglyceride } \\
\text { levels ranging } \\
\text { from } 500 \text { to } \\
2,000 \mathrm{mg} / \mathrm{dl}\end{array}$ & $\begin{array}{l}4 \text { g EPA plus } 3.6 \\
\text { g DHA /day }\end{array}$ & 30 days & $\begin{array}{l}\text { Triglycerides and total } \\
\text { cholesterol decreases by } 41 \% \\
\text { and } 12 \% \text {. } \\
\text { HDL and LDL increases by } \\
\text { about } 4 \% \text { and } 24 \%\end{array}$ \\
\hline $\begin{array}{ll}\text { (Siasos } & \text { et } \\
\text { al., 2013) } & \end{array}$ & $\begin{array}{l}\text { Smokers, aged } \\
27.63 \pm 2.65 \\
\text { years old }\end{array}$ & $\begin{array}{l}\text { 2g/day }(46 \% \\
\text { EPA and } 38 \% \\
\text { DHA })\end{array}$ & 12 weeks & $\begin{array}{l}\text { Significant improvement in } \\
\text { FMD }(\mathrm{p}<0.05) \text { and PWV ( }< \\
0.01) \\
\text { Significantly decreased levels } \\
\text { of TNF } \alpha \text { (tumor necrosis } \\
\text { factor- } \alpha)(\mathrm{p}<0.05) \text { and IL-6 } \\
\text { (interleukin- } 6)(\mathrm{p}=0.01) \text { and }\end{array}$ \\
\hline
\end{tabular}




\begin{tabular}{|c|c|c|c|c|}
\hline & & & & $\begin{array}{l}\text { increased levels of PAI-1 } \\
\text { (plasminogen activator } \\
\text { inhibitor-1) }(\mathrm{p}=0.05)\end{array}$ \\
\hline $\begin{array}{l}\text { (Tousoulis } \\
\text { et al., 2014) }\end{array}$ & $\begin{array}{l}\text { Subjects (mean } \\
\text { age } 44 \quad \pm \quad 12 \\
\text { years) } \\
\text { MetS }\end{array}$ & $\begin{array}{l}\text { 2g/day }(46 \% \\
\text { EPA and } 38 \% \\
\text { DHA })\end{array}$ & 12 weeks & $\begin{array}{l}\text { Significant improvement in } \\
\text { FMD (flow-mediated dilation) } \\
\text { and PWV (Carotid-femoral } \\
\text { pulse wave velocity) ( } p< \\
0.001) \\
\text { Significant decreased in IL-6 } \\
\text { levels and increased PAI-1 } \\
\text { levels (p<0.05) } \\
\text { Significant decrease in fasting } \\
\text { triglyceride levels and in } \\
\text { serum total cholesterol levels } \\
(p<0.05) \text {. }\end{array}$ \\
\hline
\end{tabular}

\section{Anti - inflammatory effects}

Evidence from both human and animal studies suggests that $n-3$ PUFA has anti inflammatory effects. n-3 PUFA plays beneficial role in shifting the production of AA-derived pro - inflammatory eicosanoids to anti - inflammatory eicosanoids by competing with AA for incorporation into cell membrane or by inhibiting the enzymes COX-2 (Chitranjali et al., 2015), thereby, decreasing two- and four-series PG and TX production and increasing the three- and fiveseries PG, PGI and TX production (Adkins and Kelley 2010).

The production of several inflammatory cytokines such as TNF- $\alpha$ (tumor necrosis factor- $\alpha$ ), IL-1 $\beta$, IL-6 (interleukin-6), IL-8 etc. that may contribute towards development of atherosclerosis (Tortosa-Caparrós et al., 2017) are also reduced by supplementation with omega 3 especially fish oil capsules (Siasos et al., 2013; Simopoulos 2002; Tousoulis et al., 2014). Eicosapentaenoic acid (EPA) on oxidation act as potent inhibitor of leukocyte interactions with the endothelium and thus improves inflammation (Sethi 2002).
EPA is oxygenated to produce the E-series resolvins while DHA produced resolvins or protectins of the D-series (Calder 2007). Resolvins and protectins exhibit their antiinflammatory properties by inhibiting the action of leukocyte and direct impact on macrophage-directed clearance mechanisms (Serhan 2010).). It possesses its beneficial effects in the picomolar and nanomolar range (Serhan et al., 2002) and therefore contributes towards reducing inflammations associated with atherosclerosis.

\section{Endothelial dysfunction}

Omega-3 stimulates the activity of nitric oxide synthase enzyme responsible for nitric oxide production. In this way, omega-3 improves arterial stiffness and endothelial function in patients with high risk of cardiovascular disease (Casanova et al., 2017).

\section{Nutritional considerations for omega 3}

The therapeutic strategy for preventing cardiovascular disease (CVD) is mainly through increasing the use of omega -3 fatty acids. Supplementation with omega-3 
polyunsaturated fatty acids possesss cardioprotective effects through improving lipid profile, control cardiac arrhythmia, reduces platelet aggregation, improves vascular endothelial function and prevents inflammations associated with atherosclerosis (Nishizaki et al., 2017). Among all omega 3, DHA is most potent followed by EPA and ALA in preventing cardiovascular disease (CVD). Conversion of ALA to EPA are approximately $0.2 \%$ to $6 \%$ and the synthesis of DHA is $0.05 \%$ or less. Conversion of ALA to EPA and DHA is higher in women than men of same age (Burdge and Wootton 2002) is due to the action of oestrogen that may regulate the desaturation/elongation pathway. Thus, higher level of DHA is found in women using oral contraceptive pill, postmenopausal women receiving oestrogen-based hormone replacement therapy and in pregnant women (due to increase in secretion of oestrogen by the placenta) (Burdge 2006). So, walnuts and flaxseed being very good source of ALA should be included in the diet for promoting healthy heart but at the same time, fish oil supplementation is necessary for reducing the risk of cardiovascular disease.

\section{Flaxseed}

Results from various epidemiological studies (Table 1) suggests that consumption of 12 $25 \mathrm{ml} /$ day of flaxseed oil or $28-40 \mathrm{gm} /$ day of ground flaxseed powder for $2-3$ months duration plays beneficial role in significant reduction of SBP, DBP, total cholesterol, TG, LDL levels and causes an increase in serum level of ALA, EPA, HDL, Nitric oxide that helps in primary and secondary prevention of cardiovascular disease.

\section{Walnut}

The cardioprotective benefits of walnut are attributed to its fatty acid profile. It is rich in omega 3 fatty acid and has 4.2: 1 omega 6 to omega 3 ratio that is beneficial in prevention of CVD. $30 \mathrm{~g}$ of walnut consumed for five times per week for five weeks shows decrease in total cholesterol and LDL cholesterol (Olmedilla-Alonso et al., 2008). Replacing 30 $\mathrm{g}$ of saturated fat with $43 \mathrm{~g}$ of walnut significantly reduced LDL-cholesterol and apolipoprotein-B but no effect was seen on biomarkers of inflammation and endothelial dysfunction (Wu et al., 2014). Consumption of $42.5 \mathrm{~g}$ of walnuts per $2400 \mathrm{kcal}$ for 6 days in a week cause an increase in plasma EPA, DHA, ALA and decrease in AA (Chiang et $a l ., 2012$ ). Daily ingestion of $56 \mathrm{~g}$ of walnuts for 16 weeks causes improvement in FMD and reduction in systolic blood pressure (Katz et al., 2012). Thus, consumption of 30 to $60 \mathrm{~g}$ of walnut daily helps in helps in reducing risk of cardiovascular disease and coronary heart disease (Hayes et al., 2016).

\section{Effect of fish oil supplements on cardiovascular disease risk factors}

There are several pathways that explain long chain omega-3 polyunsaturated fatty acids ( $n$ - 3 LC PUFAs) intake could potentially alter risk for fatal and nonfatal cardiac events. The mechanisms through which $\mathrm{n}-3$ LC PUFAs intake might alter CVD risk have been reviewed in previous sections in detail but the dose for most of these effects have not been fully and clearly described elsewhere. Table 2 shows the effects of fish oil consumption on risk factors for cardiovascular disease.

\section{Effect of fish oil on plasmalipid profile}

Literature indicates that elevated triglyceride levels are an important independent risk factor for coronary heart disease. As shown in Table 2, a significant reduction in plasma triglycerides is a common effect of fish oil supplementation. Dose ranging from $2600-$ $4000 \mathrm{mg}$ of EPA and 1200 - $3600 \mathrm{mg}$ for DHA given for 1 month period (Caniato et 
al., 2006, Grenon et al., 2015 and Samuel et al., 2011) or EPA (1860 mg) and DHA (1500 $\mathrm{mg}$ ) given for $6-12$ months period (Bays 2006, Elajami et al., 2017) was found to be beneficial in controlling hypertriglyceridemia and increasing HDL level. But at the same time, there is slight increase in plasma total cholesterol and LDL level. The rise in total cholesterol and LDL cholesterol is therefore of concern. The elevation resulting from omega-3 fatty acids supplementation, however, may not be a harmful one due to elevations in larger, cardioprotective apolipoprotein subfractions rather than atherogenic subfractions (Jacotot, 1996).

Preventive effect of fish oil on hypertension, endothelial function and atherosclerosis

Endothelial dysfunction can be seen as an inherent feature in subjects with heart disease. Endothelial function assessed by flow mediated dilation (FMD) is related to the principal cardiovascular risk factors (Witte $e t$ al., 2005). The primary cause of FMD is release of nitric oxide by endothelial cells (Raitakari and Celermajer, 2000). Pulse Wave Velocity (PWV) is a measure of arterial stiffness. Results from Table 2 shows that fish oil capsule containing 920 - $1080 \mathrm{mg}$ of EPA and $720-760 \mathrm{mg}$ of DHA when given for $2-$ 3 months exerts beneficial effect on endothelial function by significant improvement in FMD and reduction in PWV (Casanova et al., 2017, Oikonomou et al., 2018, Siasos et al., 2013, Tousoulis et al., 2014). Fish oil capsules providing $1800 \mathrm{mg}$ of EPA and $1500 \mathrm{mg}$ of DHA given for 1 month significantly reduces non - calcified and fibrous, calcified plaque formation in patients with coronary artery disease (Alfaddagh et al., 2017). Omega-3 PUFAs causes reduction in plaque formation and improvement in endothelial dysfunction by restoring nitric oxide bioavailability (Zanetti et al., 2017) thus, reducing cardiovascular disease risk such as hypertension and atherosclerosis.

\section{Other cardioprotective benefits of fish oil supplementation}

Fish oil $6 \mathrm{~g} /$ day containing a total dose of docosahexaenoic acid (DHA) $1.5 \mathrm{~g}$ and eicosapentaenoic acid (EPA) $0.3 \mathrm{~g}$ given for 30 days shows antifibrillatory effect in patients with paroxysmal atrial fibrillation (Kumar et al., 2011). Fish oil capsule containing $540 \mathrm{mg}$ of EPA and $360 \mathrm{mg}$ of DHA given for 45 days decreases tachycardia and arrhythmias in patients with ischemic heart disease (Metcalf et al., 2008) (Table 2).

In conclusion, consumption of fatty fish at least 2 servings per week is recommended for patients without coronary artery disease as fatty fish is high in EPA and DHA (Lichtenstein et al., 2006). Fish oil supplements are suggested as an alternative to fatty fish consumption for secondary prevention of CAD (Weitz et al., 2010).

\section{References}

Adili, R., Voigt, E.M., Bormann, J.L., Foss, K.N., Hurley, L.J., Meyer, E.S., Veldman, A.J., Mast, K.A., West, J.L., Whiteheart, S.W. and Holinstat, M., 2017. In vivo modeling of docosahexaenoic acid and eicosapentaenoic acid-mediated inhibition of both platelet function and accumulation in arterial thrombi. Platelets, pp.1-9.

Adkins, Y. and Kelley, D.S., 2010. Mechanisms underlying the cardioprotective effects of omega-3 polyunsaturated fatty acids. The Journal of nutritional biochemistry, 21(9), pp.781-792.

Akrami, A., Nikaein, F., Babajafari, S., Faghih, S. and Yarmohammadi, H., 2017. Comparison of the effects of flaxseed oil and sunflower seed oil consumption on serum glucose, lipid 
profile, blood pressure, and lipid peroxidation in patients with metabolic syndrome. Journal of clinical lipidology.

Alfaddagh, A., Elajami, T.K., Ashfaque, H., Saleh, M., Bistrian, B.R. and Welty, F.K., 2017. Effect of Eicosapentaenoic and Docosahexaenoic Acids Added to Statin Therapy on Coronary Artery Plaque in Patients With Coronary Artery Disease: A Randomized Clinical Trial. Journal of the American Heart Association, 6(12), p.e006981.

Arca, M., Borghi, C., Pontremoli, R., De Ferrari, G.M., Colivicchi, F., Desideri, G. and Temporelli, P.L., 2017. Hypertriglyceridemia and omega-3 fatty acids: their often overlooked role in cardiovascular disease prevention. Nutrition, Metabolism and Cardiovascular Diseases. 28(3):197205.

Arroyo, L.H. and Lee, R.T., 1999. Mechanisms of plaque rupture: mechanical and biologic interactions. Cardiovascular research, 41(2), pp.369375 .

Balogun, K.A. and Cheema, S.K., 2015. Cardioprotective Role of Omega-3 Polyunsaturated Fatty Acids Through the Regulation of Lipid Metabolism. In Pathophysiology and Pharmacotherapy of Cardiovascular Disease (pp. 563588). Adis, Cham.

Bays, H., 2006. Clinical overview of Omacor: a concentrated formulation of omega-3 polyunsaturated fatty acids. American Journal of Cardiology, 98(4), pp.71-76.

Benes, L.B., Bassi, N.S., Kalot, M.A. and Davidson, M.H., 2018. Evolution of Omega-3 Fatty Acid Therapy and Current and Future Role in the Management of Dyslipidemia. Cardiology clinics. 36(2): pp. 277 285.

Bloedon, L.T., Balikai, S., Chittams, J.,
Cunnane, S.C., Berlin, J.A., Rader, D.J. and Szapary, P.O., 2008. Flaxseed and cardiovascular risk factors: results from a double blind, randomized, controlled clinical trial. Journal of the American College of Nutrition, 27(1), pp.65-74.

Burdge, G.C., 2006. Metabolism of $\alpha$ linolenic acid in humans. Prostaglandins, leukotrienes and essential fatty acids, 75(3), pp.161-168.

Burdge, G.C. and Wootton, S.A., 2002. Conversion of $\alpha$-linolenic acid to eicosapentaenoic, docosapentaenoic and docosahexaenoic acids in young women. British Journal of Nutrition, 88(4), pp.411-420.

Calder, P.C., 2007. Immunomodulation by omega-3 fatty acids. Prostaglandins, leukotrienes and essential fatty acids, 77(5-6), pp.327-335.

Caniato, R.N., Alvarenga, M.E. and Angel Garcia-Alcaraz, M., 2006. Effect of omega-3 fatty acids on the lipid profile of patients taking clozapine. Australian $\&$ New Zealand Journal of Psychiatry, 40(8), pp.691-697.

Cardiovascular disease. [internet]; [accessed 2018 may 1]. https://en.wikipedia.org/wiki/Cardiovas cular_disease.

Casanova, M.A., Medeiros, F., Trindade, M., Cohen, C., Oigman, W. and Neves, M.F., 2017. Omega-3 fatty acids supplementation improves endothelial function and arterial stiffness in hypertensive patients with hypertriglyceridemia and high cardiovascular risk. Journal of the American Society of Hypertension, 11(1), pp.10-19.

Chiang, Y.L., Haddad, E., Rajaram, S., Shavlik, D. and Sabaté, J., 2012. The effect of dietary walnuts compared to fatty fish on eicosanoids, cytokines, soluble endothelial adhesion molecules and lymphocyte subsets: a randomized, 
controlled crossover trial. Prostaglandins, Leukotrienes and Essential Fatty Acids, 87(4-5), pp.111117.

Chistiakov, D.A., Melnichenko, A.A., Myasoedova, V.A., Grechko, A.V. and Orekhov, A.N., 2017. Mechanisms of foam cell formation in atherosclerosis. Journal of Molecular Medicine, 95(11), pp.1153-1165.

Chitranjali, T., Anoop, P.C. and Muraleedhara, G.K., 2015. Omega-3 fatty acid concentrate from Dunaliella salina possesses anti-inflammatory properties including blockade of $\mathrm{NF}-\kappa \mathrm{B}$ nuclear translocation. Immunopharmacology and immunotoxicology, 37(1), pp.81-89.

Cullen, P., Baetta, R., Bellosta, S., Bernini, F., Chinetti, G., Cignarella, A., von Eckardstein, A., Exley, A., Goddard, M., Hofker, M. and Hurt-Camejo, E., 2003. Rupture of the atherosclerotic plaque: does a good animal model exist?. Arteriosclerosis, thrombosis, and vascular biology, 23(4), pp.535-542.

Das, S.K. and Banerjee, T.K., 2008. Stroke: indian scenario. Circulation, 118(25), pp.2719-2724.

DeCaterina, R., Giannessi, D., Mazzone, A., Bernini, W., Lazzerini, G., Maffei, S., Cerri, M., Salvatore, L. and Weksler, B., 1990. Vascular prostacyclin is increased in patients ingesting omega-3 polyunsaturated fatty acids before coronary artery bypass graft surgery. Circulation, 82(2), pp.428-438.

Dodin, S., Cunnane, S.C., Mâsse, B., Lemay, A., Jacques, H., Asselin, G., TremblayMercier, J., Marc, I., Lamarche, B., Légaré, F. and Forest, J.C., 2008. Flaxseed on cardiovascular disease markers in healthy menopausal women: a randomized, double-blind, placebocontrolled trial. Nutrition, 24(1), pp.2330 .
Dokholyan, R.S., Albert, C.M., Appel, L.J., Cook, N.R., Whelton, P. and Hennekens, C.H., 2004. A trial of omega-3 fatty acids for prevention of hypertension. American Journal of Cardiology, 93(8), pp.1041-1043.

Doshi, D. and Marx, S.O., 2009. Ion channels, transporters, and pumps as targets for heart failure. Journal of cardiovascular pharmacology, 54(4), p.273.

Dunstan, D.W., Mori, T.A., Puddey, I.B., Beilin, L.J., Burke, V., Morton, A.R. and Stanton, K.G., 1997. The independent and combined effects of aerobic exercise and dietary fish intake on serum lipids and glycemic control in NIDDM: a randomized controlled study. Diabetes care, 20(6), pp.913-921.

Dyerberg, J., Bang, H.O., Stoffersen, E., Moncada, S. and Vane, J.R., 1978. Eicosapentaenoic acid and prevention of thrombosis and atherosclerosis?. The Lancet, 312(8081), pp.117-119.

Elajami, T.K., Alfaddagh, A., Lakshminarayan, D., Soliman, M., Chandnani, M. and Welty, F.K., 2017. Eicosapentaenoic and docosahexaenoic acids attenuate progression of albuminuria in patients with type 2 diabetes mellitus and coronary artery disease. Journal of the American Heart Association, 6(7), p.e004740.

Endo, J. and Arita, M., 2016. Cardioprotective mechanism of omega3 polyunsaturated fatty acids. Journal of cardiology, 67(1), pp.22-27.

Engler, M.M. and Engler, M.B., 2006. Omega-3 fatty acids: role in cardiovascular health and disease. Journal of Cardiovascular Nursing, 21(1), pp.17-24.

Gao, L.G., Cao, J., Mao, Q.X., Lu, X.C., Zhou, X.L. and Fan, L., 2013. Influence of omega-3 polyunsaturated fatty acidsupplementation on platelet aggregation in humans: a meta-analysis of 
randomized controlled trials. Atherosclerosis, 226(2), pp.328-334.

Grenon, S.M., Owens, C.D., Nosova, E.V., Hughes- Fulford, M., Alley, H.F., Chong, K., Perez, S., Yen, P.K., Boscardin, J., Hellmann, J. and Spite, M., 2015. Short- Term, High- Dose Fish Oil Supplementation Increases the Production of Omega- 3 Fatty AcidDerived Mediators in Patients With Peripheral Artery Disease (the OMEGA- PAD I Trial). Journal of the American Heart Association, 4(8), p.e002034.

Harris, W.S., 2006. The omega-6/omega-3 ratio and cardiovascular disease risk: uses and abuses. Current atherosclerosis reports, 8(6), pp.453-459.

Harris, W.S. and Bulchandani, D., 2006. Why do omega-3 fatty acids lower serum triglycerides?. Current opinion in lipidology, 17(4), pp.387-393.

Harris, W.S., Miller, M., Tighe, A.P., Davidson, M.H. and Schaefer, E.J., 2008. Omega-3 fatty acids and coronary heart disease risk: clinical and mechanistic perspectives. Atherosclerosis, 197(1), pp.12-24.

Harrison, N. and Abhyankar, B., 2005. The mechanism of action of omega-3 fatty acids in secondary prevention postmyocardial infarction. Current medical research and opinion, 21(1), pp.95-100.

Hayes, D., Angove, M.J., Tucci, J. and Dennis, C., 2016. Walnuts (Juglans regia) chemical composition and research in human health. Critical reviews in food science and nutrition, 56(8), pp.1231-1241.

Institute of Health Metrics and Evaluation. GBD Profile: India. http://www.healthdata.org/sites/default/f iles/files/country_profiles/GBD/ihme_g bd_country_report_india.pdf. Accessed on 8 May, 2018.

Jackson, S.P., 2007. The growing complexity of platelet aggregation. Blood, 109(12), pp.5087-5095.

Jacotot, B., 1996. LpAI lipoproteins and omega-3 fatty acids. Omega-3 Lipoproteins and Atherosclerosis. Paris: John Libbey Eurotext, pp.117-128.

Jeansen, S., Witkamp, R.F., Garthoff, J.A., van Helvoort, A. and Calder, P.C., 2017. Fish oil LC-PUFAs do not affect blood coagulation parameters and bleeding manifestations: Analysis of 8 clinical studies with selected patient groups on omega-3-enriched medical nutrition. Clinical Nutrition. 37(3): pp. $948-957$.

Kahan, T. and Bergfeldt, L., 2005. Left ventricular hypertrophy in hypertension: its arrhythmogenic potential. Heart, 91(2), pp.250-256.

Katholi, R.E. and Couri, D.M., 2011. Left ventricular hypertrophy: major risk factor in patients with hypertension: update and practical clinical applications. International journal of hypertension, 2011.

Katz, D.L., Davidhi, A., Ma, Y., Kavak, Y., Bifulco, L. and Njike, V.Y., 2012. Effects of walnuts on endothelial function in overweight adults with visceral obesity: a randomized, controlled, crossover trial. Journal of the American College of Nutrition, 31(6), pp.415-423.

Kelley, D.S., Siegel, D., Vemuri, M. and Mackey, B.E., 2007. Docosahexaenoic acid supplementation improves fasting and postprandial lipid profiles in hypertriglyceridemic men-. The American journal of clinical nutrition, 86(2), pp.324-333.

Kenny, D., Warltier, D.C., Pleuss, J.A., Hoffmann, R.G., Goodfriend, T.L. and Egan, B.M., 1992. Effect of omega-3 fatty acids on the vascular response to angiotensin in normotensive men. The American journal of cardiology, 70(15), 
pp.1347-1352.

Krouwer, V.J., Hekking, L.H., LangelaarMakkinje, M., Regan-Klapisz, E. and Post, J.A., 2012. Endothelial cell senescence is associated with disrupted cell-cell junctions and increased monolayer permeability. Vascular cell, 4(1), p.12.

Kumar, S., Sutherland, F., Teh, A.W., Heck, P.M., Lee, G., Garg, M.L. and Sparks, P.B., 2011. Effects of chronic omega-3 polyunsaturated fatty acid supplementation on human pulmonary vein and left atrial electrophysiology in paroxysmal atrial fibrillation. American Journal of Cardiology, 108(4), pp.531535.

Lagarde, M., Guichardant, M., BernoudHubac, N., Calzada, C. and Véricel, E., 2018. Oxygenation of polyunsaturated fatty acids and oxidative stress within blood platelets. Biochimica et Biophysica Acta (BBA)-Molecular and Cell Biology of Lipids.

Lao, K.H., Zeng, L. and Xu, Q., 2015. Endothelial and smooth muscle cell transformation in atherosclerosis. Current opinion in lipidology, 26(5), pp.449-456.

Legein, B., Temmerman, L., Biessen, E.A. and Lutgens, E., 2013. Inflammation and immune system interactions in atherosclerosis. Cellular and Molecular Life Sciences, 70(20), pp.3847-3869.

Lichtenstein AH, Appel LJ, Brands M, et al., Diet and lifestyle recommendations revision 2006: a scientific statement from the American Heart Association Nutrition Committee. Circulation. 2006;114:82-96.

Machado, A.M., de Paula, H., Cardoso, L.D. and Costa, N.M., 2015. Effects of brown and golden flaxseed on the lipid profile, glycemia, inflammatory biomarkers, blood pressure and body composition in overweight adolescents.
Nutrition, 31(1), pp.90-96.

Maki, K.C., Van Elswyk, M.E., McCarthy, D., Hess, S.P., Veith, P.E., Bell, M., Subbaiah, P. and Davidson, M.H., 2005. Lipid responses to a dietary docosahexaenoic acid supplement in men and women with below average levels of high density lipoprotein cholesterol. Journal of the American College of Nutrition, 24(3), pp.189-199.

Metcalf, R.G., Sanders, P., James, M.J., Cleland, L.G. and Young, G.D., 2008. Effect of dietary n-3 polyunsaturated fatty acids on the inducibility of ventricular tachycardia in patients with ischemic cardiomyopathy. American Journal of Cardiology, 101(6), pp.758761.

Moreno, C., Macías, Á., Prieto, Á., De La Cruz, A., González, T. and Valenzuela, C., 2012. Effects of $n-3$ polyunsaturated fatty acids on cardiac ion channels. Frontiers in physiology, 3, p.245.

Mori, T.A., Burke, V., Puddey, I.B., Watts, G.F., O'Neal, D.N., Best, J.D. and Beilin, L.J., 2000. Purified eicosapentaenoic and docosahexaenoic acids have differential effects on serum lipids and lipoproteins, LDL particle size, glucose, and insulin in mildly hyperlipidemic men-. The American journal of clinical nutrition, 71(5), pp.1085-1094.

Munro, J.M. and Cotran, R.S., 1988. The pathogenesis of atherosclerosis: atherogenesis and inflammation. Laboratory investigation; a journal of technical methods and pathology, 58(3), pp.249-261.

Nishizaki, Y., Shimada, K. and Daida, H., 2017. The balance of omega-3 polyunsaturated fatty acids for-reducing residual risks in patients with coronary artery disease. Acta cardiologica, 72(3), pp.240-248. 
O'Keefe, J.H., Abuissa, H., Sastre, A., Steinhaus, D.M. and Harris, W.S., 2006. Effects of omega-3 fatty acids on resting heart rate, heart rate recovery after exercise, and heart rate variability in men with healed myocardial infarctions and depressed ejection fractions. American Journal of Cardiology, 97(8), pp.1127-1130.

Oikonomou, E., Vogiatzi, G., Karlis, D., Siasos, G., Chrysohoou, C., Zografos, T., Lazaros, G., Tsalamandris, S., Mourouzis, K., Georgiopoulos, G. and Toutouza, M., 2018. Effects of omega-3 polyunsaturated fatty acids on fibrosis, endothelial function and myocardial performance, in ischemic heart failure patients. Clinical Nutrition.

Olmedilla-Alonso, B., Granado-Lorencio, F., Herrero-Barbudo, C., Blanco-Navarro, I., Blázquez-García, S. and PérezSacristán, B., 2008. Consumption of restructured meat products with added walnuts has a cholesterol-lowering effect in subjects at high cardiovascular risk: a randomised, crossover, placebocontrolled study. Journal of the American College of Nutrition, 27(2), pp.342-348.

Paschos, G.K., Magkos, F., Panagiotakos, D.B., Votteas, V. and Zampelas, A., 2007. Dietary supplementation with flaxseed oil lowers blood pressure in dyslipidaemic patients. European journal of clinical nutrition, 61(10), p.1201.

Phang, M., Garg, M.L. and Sinclair, A.J., 2009. Inhibition of platelet aggregation by omega- 3 polyunsaturated fatty acids is gender specific-Redefining platelet response to fish oils. Prostaglandins, leukotrienes and essential fatty acids, 81(1), pp.35-40.

Phang, M., Sinclair, A.J., Lincz, L.F. and Garg, M.L., 2012. Gender-specific inhibition of platelet aggregation following omega-3 fatty acid supplementation. Nutrition, Metabolism and Cardiovascular Diseases, 22(2), pp.109-114.

Pilar, B.C., da Costa Güllich, A.A., Ströher, D.J., Zuravski, L., Mezzomo, J., Coelho, R.P., Faoro, D., Piccoli, J.D.C.E. and Manfredini, V., 2014. 28days dietary supplementation with golden flaxseed improves biochemical and oxidative parameters in patients with metabolic syndrome. Journal of Functional Foods, 10, pp.232-242.

Reddy, K.S., Shah, B., Varghese, C. and Ramadoss, A., 2005. Responding to the threat of chronic diseases in India. The Lancet, 366(9498), pp.1744-1749.

Ricklefs-Johnson, K., Johnston, C.S. and Sweazea, K.L., 2017. Ground flaxseed increased nitric oxide levels in adults with type 2 diabetes: A randomized comparative effectiveness study of supplemental flaxseed and psyllium fiber. Obesity Medicine, 5, pp.16-24.

Raitakari, O.T. and Celermajer, D.S., 2000. Research Methods in Human Cardiovascular Pharmacology edited by Dr S. Maxwell and Prof. D. Webb Flow- mediated dilatation. British journal of clinical pharmacology, 50(5), pp.397-404.

Rombaldova, M., Janovska, P., Kopecky, J. and Kuda, O., 2017. Omega-3 fatty acids promote fatty acid utilization and production of pro-resolving lipid mediators in alternatively activated adipose tissue macrophages. Biochemical and biophysical research communications, 490(3), pp.1080-1085.

Samuel, S., Peskin, B., Arondekar, B., Alperin, P., Johnson, S., Blumenfeld, I., Stone, G. and Jacobson, T.A., 2011. Estimating health and economic benefits from using prescription omega3 fatty acids in patients with severe hypertriglyceridemia. American Journal 
of Cardiology, 108(5), pp.691-697.

Scorletti, E. and Byrne, C.D., 2018. Omega-3 fatty acids and non-alcoholic fatty liver disease: evidence of efficacy and mechanism of action. Molecular aspects of medicine. https://doi.org/10.1016/j.mam.2018.03.0 01

Serhan, C.N., 2010. Novel lipid mediators and resolution mechanisms in acute inflammation: to resolve or not?. The American journal of pathology, 177(4), pp.1576-1591.

Serhan, C.N., Hong, S., Gronert, K., Colgan, S.P., Devchand, P.R., Mirick, G. and Moussignac, R.L., 2002. Resolvins: a family of bioactive products of omega- 3 fatty acid transformation circuits initiated by aspirin treatment that counter proinflammation signals. Journal of Experimental Medicine, 196(8), pp.1025-1037.

Sethi, S., 2002. Inhibition of leukocyteendothelial interactions by oxidized omega-3 fatty acids: a novel mechanism for the anti-inflammatory effects of omega-3 fatty acids in fish oil. Redox report, 7(6), pp.369-378.

Siasos, G., Tousoulis, D., Oikonomou, E., Zaromitidou, M., Verveniotis, A., Plastiras, A., Kioufis, S., Maniatis, K., Miliou, A., Siasou, Z. and Stefanadis, C., 2013. Effects of omega-3 fatty acids on endothelial function, arterial wall properties, inflammatory and fibrinolytic status in smokers: a cross over study. International journal of cardiology, 166(2), pp.340-346.

Simopoulos, A.P., 2002. Omega-3 fatty acids in inflammation and autoimmune diseases. Journal of the American College of nutrition, 21(6), pp.495-505.

Tabas, I., 2002. Lipids and atherosclerosis. In New Comprehensive Biochemistry (Vol. 36, pp. 573-597). Elsevier.

Torpy, J.M., Glass, T.J. and Glass, R.M.,
2004. Left ventricular hypertrophy. JAMA, 292(19), pp.2430-2430.

Tortosa-Caparrós, E., Navas-Carrillo, D., Marín, F. and Orenes-Piñero, E., 2017. Anti-inflammatory effects of omega 3 and omega 6 polyunsaturated fatty acids in cardiovascular disease and metabolic syndrome. Critical reviews in food science and nutrition, 57(16), pp.34213429.

Tousoulis, D., Plastiras, A., Siasos, G., Oikonomou, E., Verveniotis, A., Kokkou, E., Maniatis, K., Gouliopoulos, N., Miliou, A., Paraskevopoulos, T. and Stefanadis, C., 2014. Omega-3 PUFAs improved endothelial function and arterial stiffness with a parallel antiinflammatory effect in adults with metabolic syndrome. Atherosclerosis, 232(1), pp.10-16.

Vasan, R.S., Larson, M.G., Benjamin, E.J., Evans, J.C., Reiss, C.K. and Levy, D., 1999. Congestive heart failure in subjects with normal versus reduced left ventricular ejection fraction: prevalence and mortality in a population-based cohort. Journal of the American College of Cardiology, 33(7), pp.1948-1955.

Weitz, D., Weintraub, H., Fisher, E., \& Schwartzbard, A. Z. (2010). Fish oil for the treatment of cardiovascular disease. Cardiology in review, 18(5), 258.

Witte, D.R., Westerink, J., de Koning, E.J., van der Graaf, Y., Grobbee, D.E. and Bots, M.L., 2005. Is the association between flow-mediated dilation and cardiovascular risk limited to low-risk populations?. Journal of the American College of Cardiology, 45(12), pp.19871993.

Wu, L., Piotrowski, K., Rau, T., Waldmann, E., Broedl, U.C., Demmelmair, H., Koletzko, B., Stark, R.G., Nagel, J.M., Mantzoros, C.S. and Parhofer, K.G., 2014. Walnut-enriched diet reduces 
fasting non-HDL-cholesterol and apolipoprotein B in healthy Caucasian subjects: a randomized controlled crossover clinical trial. Metabolism-Clinical and Experimental, 63(3), pp.382-391.

Xiao, Y.F., Ke, Q., Wang, S.Y., Auktor, K., Yang, Y., Wang, G.K., Morgan, J.P. and Leaf, A., 2001. Single point mutations affect fatty acid block of human myocardial sodium channel $\alpha$ subunit $\mathrm{Na}+$ channels. Proceedings of the National Academy of Sciences,
98(6), pp.3606-3611.

Yu, X.H., Fu, Y.C., Zhang, D.W., Yin, K. and Tang, C.K., 2013. Foam cells in atherosclerosis. Clinica chimica acta, 424, pp.245-252.

Zanetti, M., Gortan Cappellari, G., Barbetta, D., Semolic, A. and Barazzoni, R., 2017. Omega 3 polyunsaturated fatty acids improve endothelial dysfunction in chronic renal failure: role of eNOS activation and of oxidative stress. Nutrients, 9(8), p.895.

\section{How to cite this article:}

Anugya Bharti and Archana Kushwaha. 2020. Cardioprotective Benefits and Nutritional Criteria of Omega -3 Fatty Acids. Int.J.Curr.Microbiol.App.Sci. 9(01): 290-307. doi: https://doi.org/10.20546/ijcmas.2020.901.034 